Check for updates

Cite this: RSC Adv., 2017, 7, 20128

Received 14th March 2017

Accepted 30th March 2017

DOI: $10.1039 / \mathrm{c} 7 \mathrm{ra03032k}$

rsc.li/rsc-advances

\title{
Chroman-4-one and pyrano[4,3-b]chromenone derivatives from the mangrove endophytic fungus Diaporthe phaseolorum SKS019†
}

\author{
Hui Cui, (D) a Meng Ding, ${ }^{a}$ Dane Huang, ${ }^{b}$ Zhengrui Zhang, ${ }^{a}$ Huiting Liu, ${ }^{a}$ \\ Hongbo Huang ${ }^{\star c}$ and Zhigang She ${ }^{\star a}$
}

Seven new compounds: diaporchromanones A-D (1-4), (-)-phomopsichin A (5a), (+)-phomopsichin B (6a), and $( \pm)$-diaporchromone A (7), along with the known (+)-phomopsichin A (5b) and (-)-phomopsichin B (6b) were isolated from an endophytic fungus Diaporthe phaseolorum SKS019. The structures of the new compounds, including their absolute configurations, were determined on the basis of HRESIMS and NMR spectroscopic data, and experimental ECD and $\mathrm{Rh}_{2}\left(\mathrm{OCOCF}_{3}\right)_{4}-$ induced CD spectra analyses. Diaporchromanone A (1)/B (2), and C (3)/D (4) are two pairs of 3-epimers, and their structures possessing 3-substituted-chroman-4-one skeleton are rarely found in natural sources. (-)-Phomopsichin A (5a) and (+)-phomopsichin B (6a) are enantiomers of $(+)$-phomopsichin A (5b) and (-)-phomopsichin B (6b), respectively. All of the isolates were evaluated for their inhibitory effects against osteoclastogenesis in the RAW 264.7 cell line using luciferase reporter gene assays. Compounds $3-6 b$ exhibited moderate inhibitory effects on osteoclastogenesis by suppressing the receptor activator of $N F-\kappa B$ by ligand-induced $N F-\kappa B$ activation.

\section{Introduction}

Chroman-4-one and $4 H$-chromen-4-one derivatives have been isolated from various natural sources, such as fungi, plants, and various marine organisms. ${ }^{1-3}$ These derivatives are reported to exhibit diverse and remarkable pharmacological activities, such as antiviral, antimicrobial, antifungal, and antitumor activities. ${ }^{3-8}$ However, 3-substituted-chroman-4-one and pyrano $[4,3-b]$ chromenone derivatives were rarely described. Until now, only one 3-substituted-chroman-4-one compound and nine pyrano[4,3-b]chromenone analogues were found in nature. ${ }^{\mathbf{9}, 10}$

Marine-derived fungi are widely recognized as prolific sources of biologically active and structurally unique natural products. ${ }^{3,11}$ As part of our ongoing investigation on bioactive metabolites from mangrove endophytic fungi, ${ }^{12-17}$ a chemical

${ }^{a}$ School of Chemistry, Sun Yat-Sen University, Guangzhou 510275, China. E-mail: cesshzhg@mail.sysu.edu.cn; Fax: +86-20-84113356; Tel: +86-20-84113356

${ }^{b}$ School of Pharmaceutical Sciences, Sun Yat-Sen University, Guangzhou 510080, China

${ }^{c}$ CAS Key Laboratory of Tropical Marine Bio-resources and Ecology, Guangdong Key Laboratory of Marine Materia Medica, South China Sea Institute of Oceanology, Chinese Academy of Sciences, 164 West Xingang Road, Guangzhou 510301, China. E-mail: huanghb@scsio.ac.cn; Fax: +86-20-34066449; Tel: +86-20-34066449

$\dagger$ Electronic supplementary information (ESI) available: Spectra of all new compounds $\left({ }^{1} \mathrm{H}\right.$ NMR, ${ }^{13} \mathrm{C}$ NMR, $2 \mathrm{D}$ NMR, and HRESIMS $)$. See DOI: $10.1039 / \mathrm{c} 7 \mathrm{ra03032 \textrm {k }}$ investigation of the mangrove endophytic fungus Diaporthe phaseolorum SKS019, isolated from a fresh branch of the mangrove plant Acanthus ilicifolius, was carried out. The $\mathrm{CH}_{2} \mathrm{Cl}_{2}$ extract of a fermentation broth of the fungus led to the isolation and identification of four chroman-4-one derivatives (1-4), and five pyrano[4,3-b]chromenone derivatives (5a-7). In bioactivity assays, compounds $\mathbf{3 - 6} \mathbf{b}$ exhibited moderate inhibitory effects on osteoclastogenesis by suppressing RANKL-induced NF- $\kappa$ B activation. Herein, details of the isolation, structure elucidation, and bioactivity of these compounds (Fig. 1) are described.
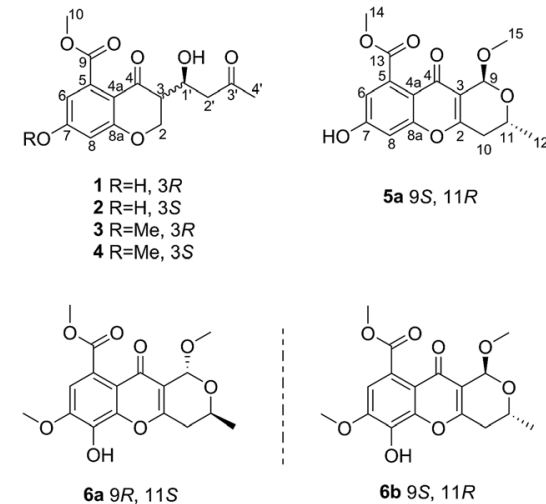

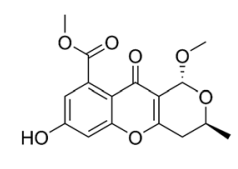

5b $9 R, 11 S$

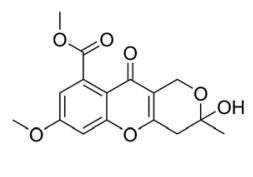

7
Fig. 1 Structures of the isolated compounds 1-7. 


\section{Results and discussion}

The mangrove endophytic fungus $D$. phaseolorum SKS019 was cultured on solid rice medium with seawater for 28 days. After incubation, the medium were extracted with $\mathrm{CH}_{2} \mathrm{Cl}_{2}$, and then the organic layers were dried under vacuum to yield solid residue. The residue was purified by various column chromatographic separations to obtain the compounds 1-7. Compound $\mathbf{5 b}$ and $\mathbf{6 b}$ were identified as (+)-phomopsichin A (5b) and (-)-phomopsichin B (6b), respectively, by comparisons of the MS and NMR data with those previously reported. ${ }^{9}$

Compound 1 was isolated as a brown powder. Its molecular formula was assigned as $\mathrm{C}_{15} \mathrm{H}_{16} \mathrm{O}_{7}$ on the basis of (-)-HRESIMS at $m / z 307.0818[\mathrm{M}-\mathrm{H}]^{-}$(calcd for $\mathrm{C}_{15} \mathrm{H}_{15} \mathrm{O}_{7}{ }^{-}, 307.0818$ ), indicating eight degrees of unsaturation. The IR spectrum of 1 exhibited absorption bands for hydroxyl $\left(3367 \mathrm{~cm}^{-1}\right)$ and conjugated carbonyl (1732 and $1620 \mathrm{~cm}^{-1}$ ) groups. In the ${ }^{1} \mathrm{H}$ NMR spectrum (Table 1), the signals for two meta-coupled aromatic protons at $\delta_{\mathrm{H}} 6.46(1 \mathrm{H}, \mathrm{d}, J=2.3 \mathrm{~Hz}, \mathrm{H}-6)$ and $6.38(1 \mathrm{H}$, $\mathrm{d}, J=2.3 \mathrm{~Hz}, \mathrm{H}-8)$, two methylene groups $\left[\delta_{\mathrm{H}} 4.55(1 \mathrm{H}, \mathrm{dd}, J=\right.$ 11.5, $5.1 \mathrm{~Hz}, \mathrm{H}-2 \mathrm{~b}), 4.42(1 \mathrm{H}, \mathrm{dd}, J=11.5,9.6 \mathrm{~Hz}, \mathrm{H}-2 \mathrm{a}) ; \delta_{\mathrm{H}} 2.81$ $\left(1 \mathrm{H}, \mathrm{dd}, J=17.3,3.6 \mathrm{~Hz}, \mathrm{H}-2^{\prime} \mathrm{b}\right), 2.74(1 \mathrm{H}, \mathrm{dd}, J=17.3,8.7 \mathrm{~Hz}, \mathrm{H}-$ $\left.\left.2^{\prime} \mathrm{a}\right)\right]$, two methine groups $\left[\delta_{\mathrm{H}} 4.49(1 \mathrm{H}, \mathrm{ddd}, J=8.7,5.1,3.6 \mathrm{~Hz}\right.$, $\left.\left.\mathrm{H}-1^{\prime}\right), \delta_{\mathrm{H}} 2.90(1 \mathrm{H}, \mathrm{ddd}, J=9.6,5.1,5.1 \mathrm{~Hz}, \mathrm{H}-3)\right]$, one methoxy group at $\delta_{\mathrm{H}} 3.93\left(3 \mathrm{H}, \mathrm{s}, \mathrm{H}_{3}-10\right)$, and one methyl group at $\delta_{\mathrm{H}} 2.19$ $\left(3 \mathrm{H}, \mathrm{s}, \mathrm{H}_{3}-4^{\prime}\right)$ were observed. The ${ }^{13} \mathrm{C}$ NMR and DEPT spectra showed 15 carbon resonances corresponding to two $\mathrm{sp}^{2}$ methine $\left(\delta_{\mathrm{C}} 110.4,104.7\right)$, two $\mathrm{sp}^{3}$ methine $\left(\delta_{\mathrm{C}} 66.5,49.6\right)$, two $\mathrm{sp}^{3}$ methylene $\left(\delta_{\mathrm{C}} 68.6,46.9\right)$, seven $\mathrm{sp}^{2}$ quaternary $\left(\delta_{\mathrm{C}} 209.2\right.$, $191.0,170.5,164.0,163.0,136.3,112.0)$, one methoxyl $\left(\delta_{\mathrm{C}} 53.4\right)$, and one methyl $\left(\delta_{\mathrm{C}} 31.0\right)$ carbons. These spectroscopic features illustrated that $\mathbf{1}$ belonged to the family of chromanone. A literature survey suggested that the ${ }^{1} \mathrm{H}$ and ${ }^{13} \mathrm{C}$ NMR data of 1 were very similar to the known polivione isolated from fungus Penicillium frequentans. ${ }^{10}$ The presence of a 1,2,3,5-tetrasubstituted aromatic ring was confirmed by the meta-coupled aromatic protons of $\mathrm{H}-6$ and $\mathrm{H}-8$. The COSY spectrum showed the ${ }^{1} \mathrm{H}-{ }^{1} \mathrm{H}$ spin system of $\mathrm{H}_{2}-2 / \mathrm{H}-3 / \mathrm{H}-1^{\prime} / \mathrm{H}_{2}-2^{\prime}$, assigned the fragment of $-\mathrm{CH}_{2}-\mathrm{CH}-\mathrm{CH}-\mathrm{CH}_{2}-$. The $\mathrm{HMBC}$ correlations from $\mathrm{H}_{2}-2$ to C-3, C-4, and C-8a, and from $\mathrm{H}-3$ to C-4 established the core structure of a chroman-4-one. The HMBC correlations (Fig. 2) from the aromatic proton $\mathrm{H}-6$ and from the methoxy protons $\mathrm{H}_{3}-10$ to the carbonyl $\mathrm{C}-9$ indicated the existence of a methyl benzoate moiety. The attachment of 7-OH group was confirmed by the HMBC correlations from $\mathrm{H}-6$ to $\mathrm{C}-7$ and from $\mathrm{H}-8$ to C-7. The substitution of a butan-2-one fragment at C-3 was inferred from the cross peaks of $\mathrm{H}_{3}-4^{\prime} / \mathrm{C}-3^{\prime}, \mathrm{C}-2^{\prime}$, and of $\mathrm{H}-\mathbf{1}^{\prime} / \mathrm{C}-2$, C-4, and $\mathrm{C}-3^{\prime}$ in the HMBC spectrum. The above mentioned data established the planar structure of $\mathbf{1}$.

There are two stereogenic centers $\left(\mathrm{C}-3\right.$ and $\left.\mathrm{C}-\mathbf{1}^{\prime}\right)$ in $\mathbf{1}$. The absolute configuration at C-3 in 1 was determined by analysis of electronic circular dichroism (ECD) spectrum using ketone octant rule. ${ }^{18}$ For cyclic aryl-ketone compounds, a modified octant rule demonstrated that the positive cotton effect (CE) for the $\mathrm{n} \rightarrow \pi^{*}$ carbonyl transition indicate $3 R$ absolute configuration, while the negative $\mathrm{CE}$ for the $\mathrm{n} \rightarrow \pi^{*}$ carbonyl transition indicate $3 S$ absolute configuration. ${ }^{18,19}$ Compound 1 showed UV

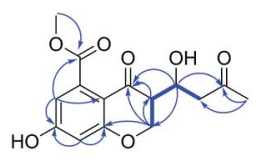

$1 / 2$

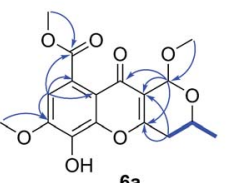

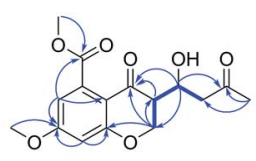

$3 / 4$

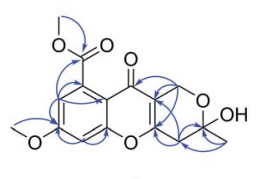

7

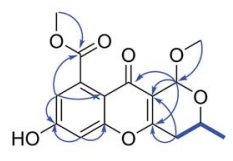

$5 a$
Fig. 2 Selected ${ }^{1} \mathrm{H}-{ }^{1} \mathrm{H}$ COSY (bold line) and $\mathrm{HMBC}$ (arrow) correlations of compounds $1-7$.

Table $1{ }^{1} \mathrm{H}$ and ${ }^{13} \mathrm{C}$ NMR (500 MHz) spectroscopic data for compounds 1 and 2

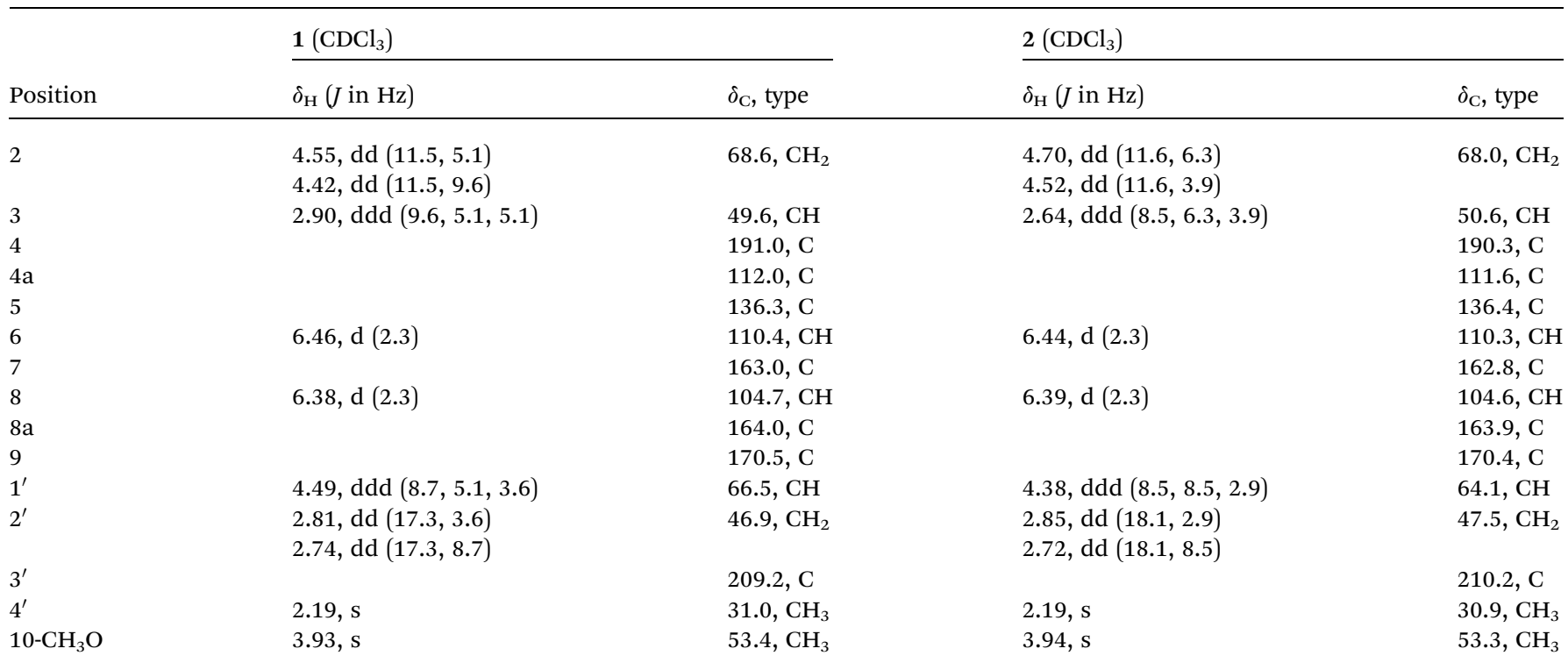


absorption bands at $279 \mathrm{~nm}\left(\pi \rightarrow \pi^{*}\right)$ and $320 \mathrm{~nm}\left(\mathrm{n} \rightarrow \pi^{*}\right)$. The ECD spectrum of 1 displayed a positive CE at $329 \mathrm{~nm}$ (Fig. 3, left) and confirmed the absolute configuration of the stereogenic center C-3 as $R$. The absolute configuration of the $\mathrm{C}-\mathbf{1}^{\prime}$ was assigned to be $\mathrm{S}$ on the basis of the $\mathrm{CD}$ spectrum for the complex of compound 1 with $\left[\mathrm{Rh}_{2}\left(\mathrm{OCOCF}_{3}\right)_{4}\right]$, which showed a positive $\mathrm{E}$ band (Fig. 5). ${ }^{\mathbf{2 0 - 2 2}}$ In addition, the predicted ECD curves of 1 were calculated by a quantum chemical method at the CAM-B3LYP/6-311+G(2d,p) level, and the theoretical ECD curve for $3 R 1^{\prime} S$-1 showed an excellent fit with the experimental one. Therefore, the absolute configuration of the stereogenic centers for 1 was assigned as $3 R$ and $1^{\prime} S$. Thus, compound 1 was named diaporchromanone A. Since the first 3-substitutedchroman-4-one derivative polivione was described in $1985,{ }^{10}$ this was the second example to report the 3-substitutedchroman-4-one analogues.

Compound 2 was isolated as a brown powder, possessing the same molecular formula $\mathrm{C}_{15} \mathrm{H}_{16} \mathrm{O}_{7}$ as 1 . The ${ }^{1} \mathrm{H}$ and ${ }^{13} \mathrm{C}$ NMR spectroscopic data (Table 1 ) of $\mathbf{2}$ were very similar to those of $\mathbf{1}$, except that the ${ }^{13} \mathrm{C}$ NMR chemical shifts at C-2, C-3, C-1 ${ }^{\prime}, \mathrm{C}-2^{\prime}\left(\delta_{\mathrm{C}}\right.$ 68.0, 50.6, 64.1, and 47.5) were different from those in $1\left(\delta_{\mathrm{C}} 68.6\right.$, 49.6, 66.5, and 46.9), respectively. Further investigations of the ${ }^{1} \mathrm{H}-{ }^{1} \mathrm{H}$ COSY and HMBC experiments (Fig. 2) indicated that 2 shared the same planar structure with 1. In the ${ }^{1} \mathrm{H}$ NMR spectrum, although the resonance value for $\mathrm{H}-3$ of $2\left(\delta_{\mathrm{H}} 2.64\right)$ was up-shifted slightly than that in $1\left(\delta_{\mathrm{H}} 2.90\right)$, the coupling constants of $\mathrm{H}-3 / \mathrm{H}_{2}-2(J=6.3,3.9 \mathrm{~Hz})$ and of $\mathrm{H}-3 / \mathrm{H}-1^{\prime}(J=8.5$ $\mathrm{Hz}$ ) were obviously different with those in $1\left(J_{\mathrm{H}-3 / \mathrm{H}-2}=9.6\right.$, $5.1 \mathrm{~Hz}, J_{\mathrm{H}-3 / \mathrm{H}-1^{\prime}}=5.1 \mathrm{~Hz}$ ). Compound 2 displayed a negative $\mathrm{CE}$ at the $\mathrm{n} \rightarrow \pi^{*}$ carbonyl transition (318 nm) in the ECD spectrum (Fig. 3, right), which confirmed $3 S$ absolute configuration via applying the octant rule. ${ }^{18}$ Furthermore, the Rh-complex of 2 displayed a positive $\mathrm{E}$ band (Fig. 5), indicating $1^{\prime} S$ absolute configuration for 2 , which was the same with that in $\mathbf{1}$. Therefore, compound $\mathbf{2}$ was identified as 3-epimer of $\mathbf{1}$, and was named diaporchromanone $\mathrm{B}$.

The molecular formula of compounds 3 and 4 were determined to be $\mathrm{C}_{16} \mathrm{H}_{18} \mathrm{O}_{7}$ by (-)-HRESIMS peak at $m / z$ 321.0970 [M $-\mathrm{H}]^{-}$, which was one $\mathrm{CH}_{2}$ unit greater than that for $\mathbf{1}$ and 2. The ${ }^{1} \mathrm{H}$ and ${ }^{13} \mathrm{C}$ NMR spectroscopic data (Table 2) of $\mathbf{3}$ and $\mathbf{4}$ resembled those of $\mathbf{1}$ and 2 , respectively, except that the additional signals for a methoxy group $\left(\delta_{\mathrm{H} / \mathrm{C}} 3.85 / 56.1\right.$ in $3 ; \delta_{\mathrm{H} / \mathrm{C}} 3.84 /$ 56.1 in 4) were observed. The methoxy group C-11 was connected to C-7 on the basis of the HMBC correlation (Fig. 2) from the methoxy protons to $\mathrm{C}-7\left(\delta_{\mathrm{C}} 164.1\right)$ in 3 and 4 . The absolute configurations of stereogenic centers for $\mathbf{3}$ and $\mathbf{4}$ were assigned as $3 R, 1^{\prime} S$, and $3 S, 1^{\prime} S$ on the basis of the same ECD absorption curves as $\mathbf{1}$ and 2 (Fig. 3), respectively. Compounds $\mathbf{3}$ and $\mathbf{4}$,
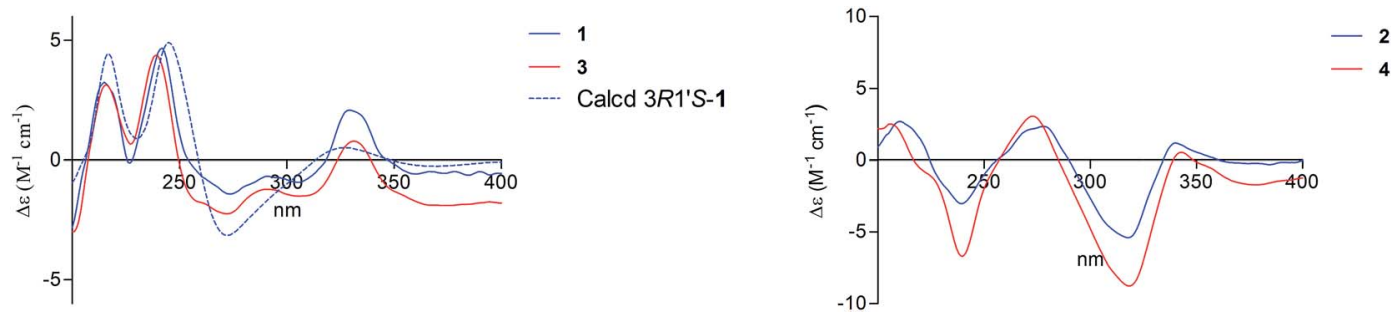

Fig. 3 Experimental and calculated ECD spectra of compounds $1 / 3$ (left) and 2/4 (right) in methanol.

Table $2{ }^{1} \mathrm{H}$ and ${ }^{13} \mathrm{C}$ NMR (500 MHz) spectroscopic data for compounds 3 and 4

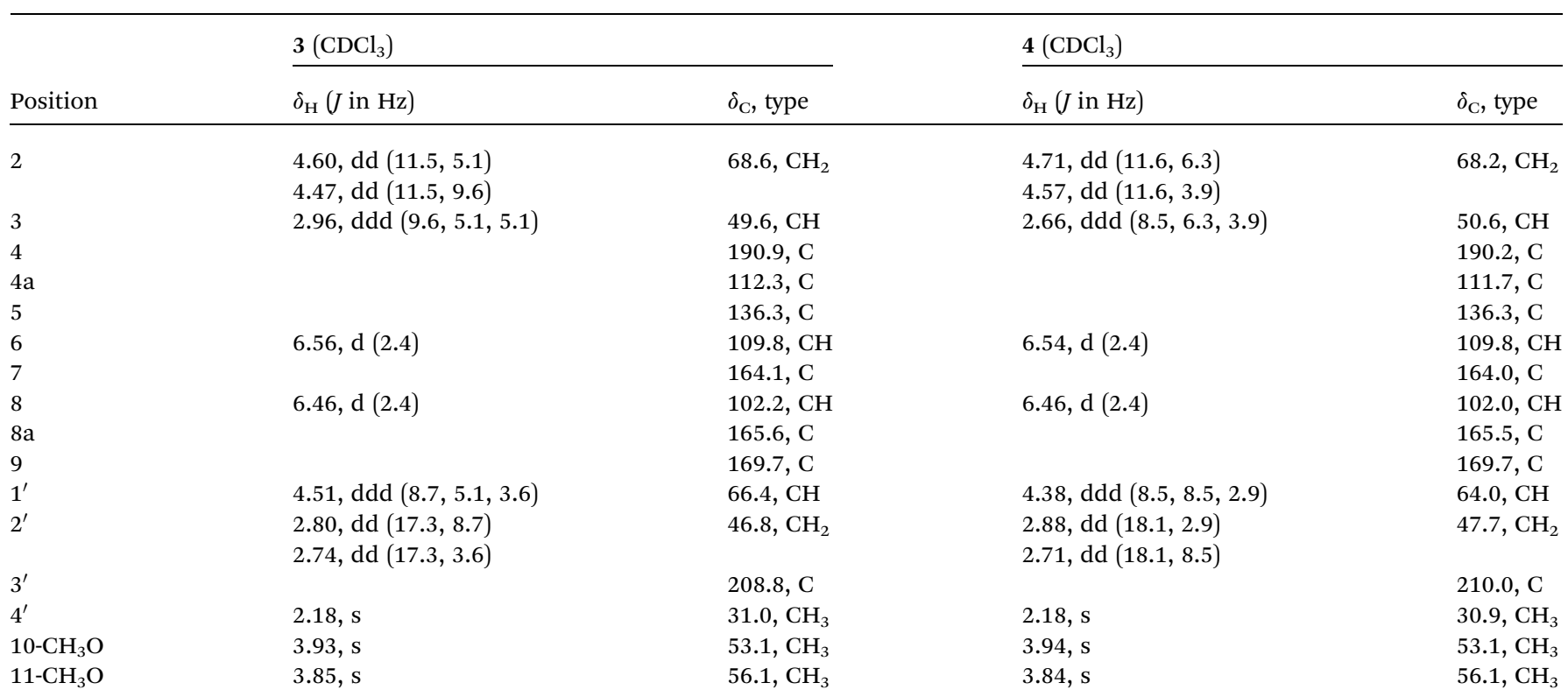


a pair of 3-epimers, were named diaporchromanones $\mathrm{C}$ and $\mathrm{D}$, accordingly.

Compound 5a was obtained as a white powder. The molecular formula of $\mathrm{C}_{16} \mathrm{H}_{16} \mathrm{O}_{7}$ was determined on the basis of (-)-HRESIMS $m / z 319.0818[\mathrm{M}-\mathrm{H}]^{-}$, representing nine degrees of unsaturation. The ${ }^{1} \mathrm{H}$ and ${ }^{13} \mathrm{C}$ NMR data (Table 3 ) of 5a were the same as the known phomopsichin A (5b), ${ }^{9}$ which was previously isolated from mangrove endophytic fungus phomopsis sp. 33\#. However, compound 5a showed a negative optical rotation value $[\alpha]_{\mathrm{D}}^{25}-12(c \quad 0.3, \mathrm{MeOH})$, which was opposite to that of $\mathbf{5 b}[\alpha]_{\mathrm{D}}^{25}+12.5$. Furthermore, compounds $5 \mathbf{a}$ and $\mathbf{5 b}$ presented reverse absorption curves in the ECD spectra (Fig. 4, left). Based on the above data, it was deduced that 5a and 5b were enantiomers, and the absolute configuration of stereogenic centers for $\mathbf{5 a}$ was assigned as $9 S, 11 R$. Finally, compound 5a was named (-)-phomopsichin A. To the best of our knowledge, compound $\mathbf{5 a}$ is the tenth example of pyrano $[4,3-b]$ chromenone derivatives from natural sources.

The molecular formula of compound $\mathbf{6 a}$ was established as $\mathrm{C}_{17} \mathrm{H}_{18} \mathrm{O}_{8}$ on the basis of (-)-HRESIMS at $\mathrm{m} / \mathrm{z} 349.0921$ [M $\mathrm{H}]^{-}$(calcd for 349.0923), indicating nine degrees of unsaturation. Detailed analysis of the ${ }^{1} \mathrm{H}$ and ${ }^{13} \mathrm{C}$ NMR data (Table 3) of 6a indicated that the ${ }^{1} \mathrm{H}$ and ${ }^{13} \mathrm{C}$ NMR data of $\mathbf{6 a}$ were the same as phomopsichin B (6b). ${ }^{9}$ As seen in compounds $\mathbf{5 a}$ and $\mathbf{5 b}$, the optical rotation value $[\alpha]_{\mathrm{D}}^{25}+16(c 0.4, \mathrm{MeOH})$ of 6 a was opposite to that of phomopsichin B (6b). Moreover, compounds $6 \mathbf{a}$ and 6b presented the reverse ECD absorption curves (Fig. 4, right). Thus, compound $\mathbf{6 a}$ was identified to be enantiomer of $\mathbf{6 b}$, and the absolute configuration of stereogenic centers for $\mathbf{6 a}$ was determined as $9 R, 11 S$. Finally, compound $\mathbf{6 a}$ was named as (+)-phomopsichin B.

Compound 7 had a molecular formula of $\mathrm{C}_{16} \mathrm{H}_{16} \mathrm{O}_{7}$, as established by the (-)-HRESIMS $m / z \quad 319.0811[\mathrm{M}-\mathrm{H}]^{-}$, implying nine degrees of unsaturation. The ${ }^{13} \mathrm{C}$ NMR data showed 16 carbons (Table 3$)$, including two $\mathrm{sp}^{2}$ methine $\left(\delta_{\mathrm{C}}\right.$ 113.0, 101.7), two $\mathrm{sp}^{3}$ methylene $\left(\delta_{\mathrm{C}} 57.5,37.1\right)$, eight $\mathrm{sp}^{2}$ quaternary $\left(\delta_{\mathrm{C}} 173.7,169.5,163.2,158.4,158.0,134.7,115.5\right.$, 114.4), one $\mathrm{sp}^{3}$ quaternary $\left(\delta_{\mathrm{C}} 95.4\right)$, two methoxyl $\left(\delta_{\mathrm{C}} 56.2\right.$, 53.2), and one methyl $\left(\delta_{\mathrm{C}} 29.5\right)$ carbons. Comparing the ${ }^{1} \mathrm{H}$ and ${ }^{13} \mathrm{C}$ NMR data of 7 with those of 5 a revealed that two $\mathrm{sp}^{3}$ methine (C-9 and C-11) in 5a were replaced by one $\mathrm{sp}^{3}$ methylene and one $\mathrm{sp}^{3}$ quaternary carbons in 7 . These changes were proved by the HMBC correlations from $\mathrm{H}_{2}-10$ to C-11, from $\mathrm{H}_{3}$ 12 to $\mathrm{C}-10$ and $\mathrm{C}-11$, and from $\mathrm{H}_{2}-9$ to $\mathrm{C}-3, \mathrm{C}-4$ and $\mathrm{C}-11$. In addition, the methoxy group $\mathrm{C}-16$ was linked to $\mathrm{C}-7$ established by the HMBC correlation (Fig. 2) from the methoxy protons $\left(\delta_{\mathrm{H}}\right.$

Table $3{ }^{1} \mathrm{H}$ and ${ }^{13} \mathrm{C}$ NMR $(500 \mathrm{MHz})$ spectroscopic data for compounds $5 \mathrm{a}$, $6 \mathrm{a}$, and 7

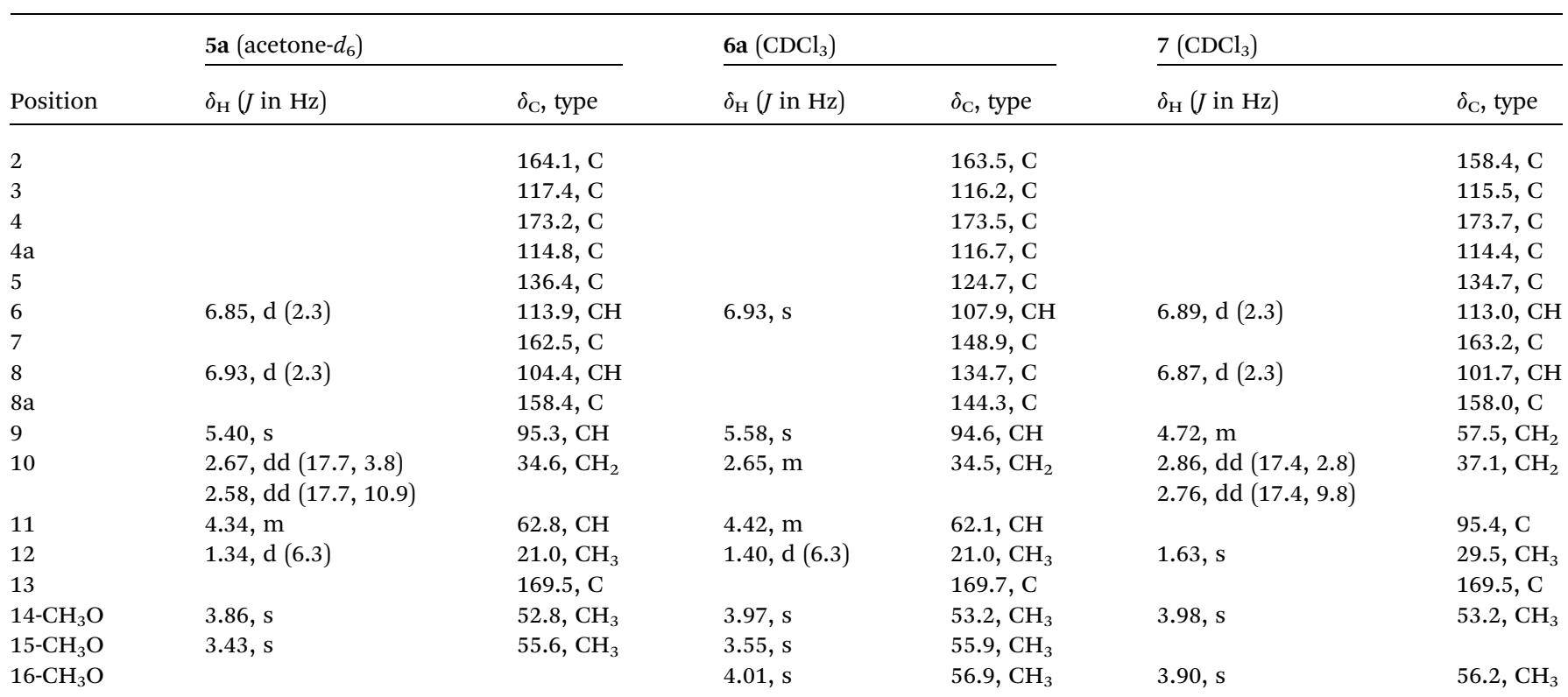
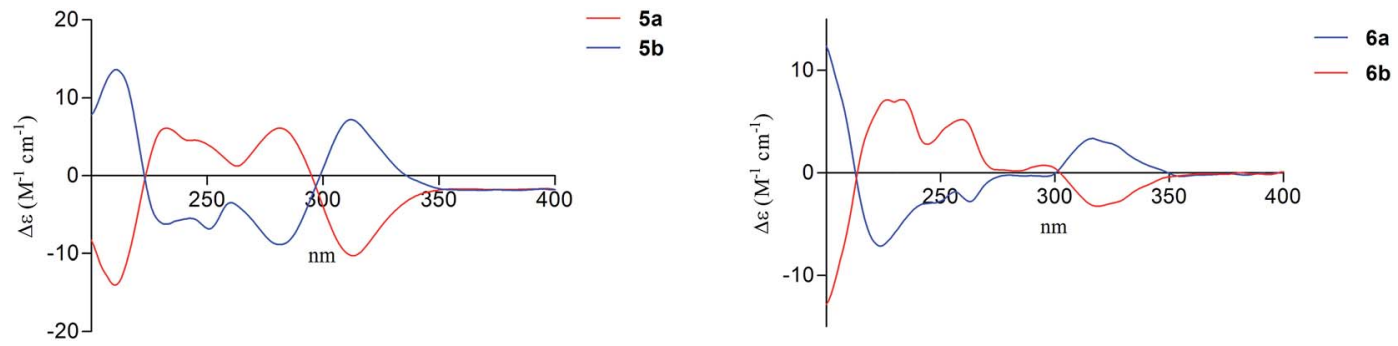

Fig. 4 Experimental ECD spectra of compounds $5 a / 5 b$ (left) and $6 a / 6 b$ (right) in methanol. 


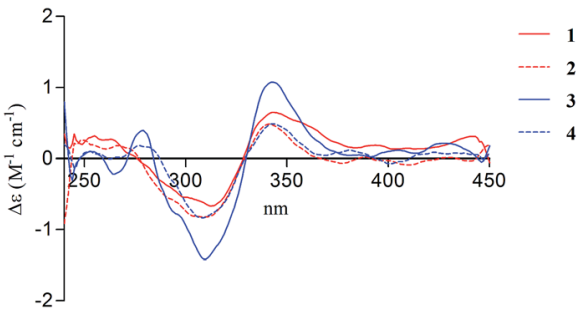

Fig. $5 C D$ spectrum of Rh-complex of 1-4 with the inherent $C D$ spectrum subtracted.

Table 4 Inhibitory effects of eight compounds on osteoclastogenesis by luciferase reporter gene assay

\begin{tabular}{|c|c|c|c|}
\hline No. & $\%$ inhibition $(50 \mu \mathrm{M})$ & $\mathrm{IC}_{50}{ }^{a}(\mu \mathrm{M})$ & $\mathrm{CC}_{50}{ }^{b}(\mu \mathrm{M})$ \\
\hline 1 & 15 & - & $>50$ \\
\hline 2 & 20 & - & $>50$ \\
\hline 3 & 51 & $43 \pm 1.3$ & $>50$ \\
\hline 4 & 60 & $41 \pm 0.3$ & $>50$ \\
\hline $5 \mathbf{a}$ & 46 & $46 \pm 0.8$ & $>50$ \\
\hline $5 \mathbf{b}$ & 50 & $43 \pm 2.1$ & $>50$ \\
\hline $6 \mathbf{a}$ & 65 & $30 \pm 1.3$ & $>50$ \\
\hline $6 \mathbf{b}$ & 70 & $28 \pm 0.5$ & $>50$ \\
\hline \multicolumn{2}{|c|}{$\mathbf{J S H}-23^{c}$} & $10.8 \pm 1.3$ & \\
\hline
\end{tabular}

3.90, $\left.\mathrm{H}_{3}-16\right)$ to $\mathrm{C}-7\left(\delta_{\mathrm{C}} 163.2\right)$. Thus, the planar structure was elucidated. Because the optical rotation value of 7 was nearly zero and the ECD spectrum of 7 didn't show absorption curves, it was deduced that diaporchromone A (7) was obtained as racemic mixture. Unfortunately, further chiral separations of 7 by HPLC using S-Chiral A or chiralcel OD columns were failed. Finally, compound 7 was named $( \pm)$ diaporchromone A.

Compounds (1-6b) were tested for their inhibitory activity of osteoclastogenesis by suppressing RANKL-induced NF- $\kappa \mathrm{B}$ activation using RAW 264.7 cell line. The results (Table 4) showed that compounds 3-6b exhibited moderate activities with $\mathrm{IC}_{50}$ values from 28 to $46 \mu \mathrm{M}$, in contrast to positive control (JSH-23, $\left.\mathrm{IC}_{50}=10.8 \mu \mathrm{M}\right)$. Interestingly, the different configurations in $\mathbf{5 a} / \mathbf{5 b}$ and $\mathbf{6 a / 6 b}$ almost didn't affect their activities. However, compounds 1 and 2 showed no inhibitory effects at a concentration of $50 \mu \mathrm{M}$. Compounds (1-6b) were tested for their cytotoxicity using MDA-MB-435 and MCF10A human cell lines. None of these compounds showed growth inhibitory activity against MDA-MB-435 and MCF10A cell lines at a concentration of $50 \mu \mathrm{M}$.

\section{Experimental section}

\section{General experimental procedures}

IR data were recorded on a Nicolet 5DX-FTIR (Thermo Fisher Scientific, Inc., Hudson, NH, USA), in KBr discs. UV data were recorded on a Shimadzu UV-240 spectrophotometer (Shimadzu, Kyoto, Japan). Optical rotations were measured on a Bellingham-Stanley ADP $440+$ polarimeter at $25{ }^{\circ} \mathrm{C}$. The ${ }^{1} \mathrm{H}$ NMR (500 MHz), ${ }^{13} \mathrm{C}$ NMR (125 MHz), and 2D NMR spectra were obtained on a Bruker AVANCE-500 (Bruker BioSpin Corporation, Billerica, MA, USA) using TMS as an internal reference. ESIMS were acquired on a Thermofisher LTQ Orbitrp Elite LCMS spectrometer (Thermo Fisher Scientific, Inc., Hudson, NH, USA), and the HRESIMS data were measured on a Micro Mass QTOF spectrometer (Waters Corporation, Milford, MA, USA). TLC analysis was carried out on silica gel plates (Marine Chemical Ltd., Qingdao, China). The chiral HPLC separation was accomplished over an S-Chiral A column (column size: $10 \times 250$ mm $5 \mu \mathrm{m}$; Acchrom Technologies Co., Ltd., Beijing, China). RP$\mathrm{C}_{18}$ silica gel (Fuji, 40-75 $\mu \mathrm{m}$, Fuji Silysia Chemical Ltd., Kasugai, Japan), silica gel (200-300 mesh, Marine Chemical Ltd., Qingdao, China), high silica gel ( $\mathrm{H}$, Marine Chemical Ltd., Qingdao, China), and Sephadex LH-20 (GE Healthcare BioSciences AB, Stockholm, Sweden) were used for column chromatography (CC). RAW264.7 cells were gifted from Professor Jiake Xu from the School of Pathology and laboratory Medicine, the University of Western Australia. Human breast cancer cell line MDA-MB-435 and immortalized non-cancer breast epithelial cells MCF10A were purchased from the cell bank of Chinese Academy of Sciences (Shanghai, China). Dulbecco's modified Eagle's medium (DMEM), fetal bovine serum (FBS), $2 \mathrm{mM} \mathrm{L}^{-1}$ glutamine, 100 units $\mathrm{mL}^{-1}$ penicillin, and $100 \mu \mathrm{g} \mathrm{mL}^{-1}$ streptomycin were obtained from Invitrogen-Gibco (Grand Island, NY, USA). RANKL was purchased from Peprotech EC Ltd. (London, UK). 3-(4,5-Dimethylthiazol-2-yl)-2,5-diphenyl tetrazolium bromide (MTT) reagent was purchased from Genview (Houston, TX, USA). 4-Methyl-N1-(3-phenylpropyl)-1,2benzenediamine (JSH-23, >98\%) was purchased from Sigma (Buchs, Switzerland), and all other chemicals were obtained from Sigma (St. Louis, USA).

\section{Fungal material}

The fungal strain SKS019 was isolated from the branches of the mangrove plant Acanthus ilicifolius collected from Shankou in Guangxi province, China. The fungus was identified by our team as Diaporthe phaseolorum SKS019, according to a molecular biological protocol by DNA amplification and sequencing of the ITS region (deposited in GenBank, accession no. KX815357). A voucher strain was deposited in School of Chemistry, Sun YatSen University, Guangzhou, China, with the access code, 2016SKS019.

\section{Fermentation, extraction and isolation}

The fungus Diaporthe phaseolorum SKS019 was grown on a solid autoclaved rice substrate medium (sixty $500 \mathrm{~mL}$ Erlenmeyer flasks, each containing $50 \mathrm{~g}$ of rice and $50 \mathrm{~mL}$ of $0.3 \%$ of saline water) for 28 days at room temperature. The mycelia and solid rice medium were extracted with $\mathrm{CH}_{2} \mathrm{Cl}_{2}$ for three times. The organic solvents were evaporated under reduced pressure to yield a crude extract (26.3 g), then chromatographed on silica gel column (100 g, 100-200 mesh, $6 \times 50 \mathrm{~cm})$ eluting with a step gradient of petroleum ether (PE)-ethyl acetate (EA) (100:0; $9: 1 ; 8: 2 ; 7: 3 ; 6: 4 ; 5: 5 ; 4: 6 ; 3: 7 ; 0: 100, \mathrm{v} / \mathrm{v}$, each $500 \mathrm{~mL}$ ) 
to give nine fractions (F1-F9). F4 (1.5 g) was subjected to a silica gel column $(5.0 \times 30 \mathrm{~cm})$, eluting with gradient of $\mathrm{CH}_{2} \mathrm{Cl}_{2} /$ $\mathrm{MeOH}(100: 1)$ to yield five subfractions (F401-F405). F401 (0.5 $\mathrm{g})$ was further fractionated on Sephadex LH-20 (110 g, $110 \times 3$ $\mathrm{cm})$ eluting with $\mathrm{CH}_{2} \mathrm{Cl}_{2}-\mathrm{MeOH}(1 \mathrm{~L}, 1: 1$, v/v) to give two sets of mixtures F401a (13 mg) and F401b (9 mg). After evaluation by the ${ }^{13} \mathrm{C}$ NMR analysis, F401a and F401b both contained two sets of diastereoisomers. And then F401a was purified by HPLC on an S-Chiral A column, using hexane/2-propanol (70:30, v/v, flow rate: $\left.1.5 \mathrm{~mL} \mathrm{~min}^{-1}\right)$ as the solvent system, to yield 1 $\left(5 \mathrm{mg}, t_{\mathrm{R}}=11.5 \mathrm{~min}\right)$ and $2\left(3 \mathrm{mg}, t_{\mathrm{R}}=13.0 \mathrm{~min}\right)$, and $\mathrm{F} 401 \mathrm{~b}$ was also purified by HPLC on an S-Chiral A column, using hexane/2propanol (90:10, v/v, flow rate: $1.5 \mathrm{~mL} \mathrm{~min}^{-1}$ ) as the solvent system, to obtain $3\left(4 \mathrm{mg}, t_{\mathrm{R}}=34.9 \mathrm{~min}\right)$ and $4\left(3 \mathrm{mg}, t_{\mathrm{R}}=38.8\right.$ min). F402 (200 mg) was purified by HPLC on a semipreparative $\mathrm{SB}_{-} \mathrm{C}_{18}$ column, using $\mathrm{MeOH}-\mathrm{H}_{2} \mathrm{O}(45: 55, \mathrm{v} / \mathrm{v}$, flow rate: $1.0 \mathrm{~mL}$ $\mathrm{min}^{-1}$ ) as the solvent system, to afford F402-3 (5a/5b, $25 \mathrm{mg}$ ), F402-4 (6a/6b, $20 \mathrm{mg}$ ), and 7 (4 mg). F402-3 and F402-4 were further separated by chiral HPLC using an S-Chiral A column to yield $5 \mathbf{a}(8 \mathrm{mg})$ and $5 \mathbf{b}(10 \mathrm{mg}), \mathbf{6 a}(9 \mathrm{mg})$ and $\mathbf{6 b}(7 \mathrm{mg})$, respectively.

Diaporchromanone A (1). Brown powder; $[\alpha]_{\mathrm{D}}^{25}+23(c 0.20$, $\mathrm{MeOH}) ; \mathrm{UV}(\mathrm{MeOH}) \lambda_{\max }(\log \varepsilon) 216$ (4.4), 240 (4.1), 279 (4.1), 320 (4.0) nm; ECD (MeOH) $\lambda_{\max }(\Delta \varepsilon) 215(+3.3), 242(+4.2), 329$ (+2.0) nm; IR (KBr) $\nu_{\max } 3367,2936,1732,1620,1306,1166$ $\mathrm{cm}^{-1} ;{ }^{1} \mathrm{H}$ and ${ }^{13} \mathrm{C}$ NMR data, Table $1 ;(-)$-ESIMS $m / z$ 307.1 [M $\mathrm{H}]^{-} ;(-)$-HRESIMS at $m / z 307.0818[\mathrm{M}-\mathrm{H}]^{-}$(calcd for $\mathrm{C}_{15} \mathrm{H}_{15} \mathrm{O}_{7}$ 307.0818).

Diaporchromanone B (2). Brown powder; $[\alpha]_{\mathrm{D}}^{25}-18$ (c 0.10, $\mathrm{MeOH})$; UV (MeOH) $\lambda_{\max }(\log \varepsilon) 216$ (4.4), 240 (4.1), 279 (4.1), 320 (4.0) nm; ECD (MeOH) $\lambda_{\max }(\Delta \varepsilon) 240(-2.8), 318(-5.2) \mathrm{nm}$; IR (KBr) $\nu_{\max } 3356,2948,1716,1604,1300,1160 \mathrm{~cm}^{-1} ;{ }^{1} \mathrm{H}$ and ${ }^{13} \mathrm{C}$ NMR data, Table 1; (-)-ESIMS $m / z$ 307.1 $[\mathrm{M}-\mathrm{H}]^{-}$; (-)-HRESIMS at $\mathrm{m} / \mathrm{z} 307.0810[\mathrm{M}-\mathrm{H}]^{-}$(calcd for $\mathrm{C}_{15} \mathrm{H}_{15} \mathrm{O}_{7}$ 307.0818).

Diaporchromanone C (3). Brown powder; $[\alpha]_{\mathrm{D}}^{25}+25(c \quad 0.22$, $\mathrm{MeOH})$; UV (MeOH) $\lambda_{\max }(\log \varepsilon) 216$ (4.4), 240 (4.1), 279 (4.1), 320 (4.0) nm; ECD (MeOH) $\lambda_{\max }(\Delta \varepsilon) 215(+3.3), 242(+4.2), 329$ $(+0.7) \mathrm{nm}$; IR $(\mathrm{KBr}) \nu_{\max } 3503,2925,1725,1600,1292,1150$ $\mathrm{cm}^{-1} ;{ }^{1} \mathrm{H}$ and ${ }^{13} \mathrm{C}$ NMR data, Table 2; (-)-ESIMS $m / z 321.1[\mathrm{M}-$ $\mathrm{H}]^{-} ;(-)$-HRESIMS at $m / z 321.0970[\mathrm{M}-\mathrm{H}]^{-}$(calcd for $\mathrm{C}_{16} \mathrm{H}_{17} \mathrm{O}_{7}$ 321.0974).

Diaporchromanone $\mathbf{D}(4)$. Brown powder; $[\alpha]_{\mathrm{D}}^{25}-15(c 0.16$, $\mathrm{MeOH}) ; \mathrm{UV}(\mathrm{MeOH}) \lambda_{\max }(\log \varepsilon) 216$ (4.4), 240 (4.1), 279 (4.1), 320 (4.0) nm; ECD (MeOH) $\lambda_{\max }(\Delta \varepsilon) 240(-6.0), 318(-8.6) \mathrm{nm}$; IR (KBr) $\nu_{\max } 3458,2950,1739,1610,1298,1158 \mathrm{~cm}^{-1} ;{ }^{1} \mathrm{H}$ and ${ }^{13} \mathrm{C}$ NMR data, Table 2; (-)-ESIMS $m / z$ 321.1 $[\mathrm{M}-\mathrm{H}]^{-}$; (-)-HRESIMS at $\mathrm{m} / z 321.0973[\mathrm{M}-\mathrm{H}]^{-}$(calcd for $\mathrm{C}_{16} \mathrm{H}_{17} \mathrm{O}_{7}$ 321.0974).

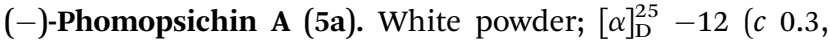
$\mathrm{MeOH}) ; \mathrm{UV}(\mathrm{MeOH}) \lambda_{\max }(\log \varepsilon) 218$ (4.4), 290 (4.0) nm; ECD $(\mathrm{MeOH}) \lambda_{\max }(\Delta \varepsilon) 211(-8.6), 233(+6.3), 248(+4.3), 284(+6.1)$, $314(-10.5) \mathrm{nm}$; IR (KBr) $\nu_{\max } 3410,2925,1744,1655,1287,1225$ $\mathrm{cm}^{-1} ;{ }^{1} \mathrm{H}$ and ${ }^{13} \mathrm{C}$ NMR data, Table $3 ;(-)$-ESIMS $m / z 319.1[\mathrm{M}-$ $\mathrm{H}]^{-} ;(-)$-HRESIMS at $m / z 319.0818[\mathrm{M}-\mathrm{H}]^{-}\left(\right.$calcd for $\mathrm{C}_{16} \mathrm{H}_{15} \mathrm{O}_{7}$ 319.0818).
(+)-Phomopsichin B (6a). White powder; $[\alpha]_{\mathrm{D}}^{25}+16(c \quad 0.4$, $\mathrm{MeOH}) ; \mathrm{UV}(\mathrm{MeOH}) \lambda_{\max }(\log \varepsilon) 238$ (4.4), 299 (3.8) nm; ECD $(\mathrm{MeOH}) \lambda_{\max }(\Delta \varepsilon) 224$ (-6.6), 250 (-3.0), $265(-2.6), 318$ $(+3.1) \mathrm{nm}$; IR (KBr) $\nu_{\max } 3421,2944,1726,1658,1429,1357,1110$ $\mathrm{cm}^{-1} ;{ }^{1} \mathrm{H}$ and ${ }^{13} \mathrm{C}$ NMR data, Table 3; (-)-ESIMS $m / z 349.1$ [M $\mathrm{H}]^{-} ;(-)$-HRESIMS at $m / z$ 349.0921 $[\mathrm{M}-\mathrm{H}]^{-}$(calcd for $\mathrm{C}_{17} \mathrm{H}_{17} \mathrm{O}_{8}$ 349.0923).

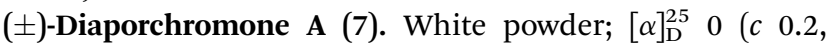
$\mathrm{MeOH}) ; \mathrm{UV}(\mathrm{MeOH}) \lambda_{\max }(\log \varepsilon) 220$ (4.4), 290 (4.0) nm; IR (KBr) $\nu_{\max } 3420,2923,1736,1615,1292,1151 \mathrm{~cm}^{-1} ;{ }^{1} \mathrm{H}$ and ${ }^{13} \mathrm{C}$ NMR data, Table 3; (-)-ESIMS $m / z 319.1[\mathrm{M}-\mathrm{H}]^{-}$; (-)-HRESIMS at $m$ / $z 319.0811[\mathrm{M}-\mathrm{H}]^{-}$(calcd for $\mathrm{C}_{16} \mathrm{H}_{15} \mathrm{O}_{7} 319.0818$ ).

\section{Determination of absolute configurations of the secondary alcohol in compounds 1-4}

According to the published procedure, ${ }^{20,22}$ compounds 1-4 (0.5 $\mathrm{mg}$ ) were dissolved in a dry solution of the stock $\left[\mathrm{Rh}_{2}\left(\mathrm{OCOCF}_{3}\right)_{4}\right]$ complex $(1.5 \mathrm{mg})$ in $\mathrm{CH}_{2} \mathrm{Cl}_{2}(200 \mu \mathrm{L})$. The first $\mathrm{CD}$ spectrum was recorded immediately after mixing, and its time evolution was monitored until stationary (about $10 \mathrm{~min}$ after mixing). The inherent CD was subtracted. The observed sign of the $\mathrm{E}$ band at $350 \mathrm{~nm}$ in the induced CD spectrum was correlated to the absolute configuration of the $\mathrm{C}-\mathbf{1}^{\prime}$ secondary alcohol.

\section{Cytotoxicity assay}

As our previous reported method. ${ }^{12}$ Human breast cancer cell line MDA-MB-435 and immortalized non-cancer breast epithelial cells MCF10A were cultured in Dulbecco's modified Eagle's medium (DMEM) (Invitrogen, Carlsbad, CA, USA) supplemented with $5 \%$ fetal bovine serum (Hyclone, Logan, UT, USA), $100 \mu \mathrm{g} \mathrm{mL}^{-1}$ streptomycin, $2 \mathrm{mM} \mathrm{L}^{-1}$ glutamine and 100 units $\mathrm{mL}^{-1}$ penicillin (Invitrogen). The cultures were maintained at $37{ }^{\circ} \mathrm{C}$ in a humidified atmosphere of $5 \% \mathrm{CO}_{2}$.

Cells were seeded in 96-well flat-bottom plates at a density of $1 \times 10^{4}$ cells per well and cultured in a humidified incubator for $24 \mathrm{~h}$, followed by exposure to various concentrations of compounds for $48 \mathrm{~h}$. Subsequently, $20 \mu \mathrm{L}$ of 3-(4,5dimethylthiazol-2-yl)-2,5-diphenyl tetrazolium bromide (MTT) reagent (Genview, Houston, TX, USA) dissolved in phosphatebuffered saline (PBS) ( $\mathrm{pH}$ 7.4) at a concentration of $5 \mathrm{mg}$ $\mathrm{mL}^{-1}$ was added to each well, and the cells were incubated for additional $4 \mathrm{~h}$. The MTT-formazan crystals formed were dissolved in $150 \mu \mathrm{L}$ DMSO (Sangon Biotech, Shanghai, China), and the absorbance was measured at $570 \mathrm{~nm}$ with a reference wavelength of $630 \mathrm{~nm}$ using a microplate reader. Cell growth inhibition was determined using the following formula according to a previously published method: growth inhibition $(\%)=(1-$ OD of treated cells/OD of control cells $) \times 100 \%$. The half maximal inhibitory concentration $\left(\mathrm{IC}_{50}\right)$ was calculated from the dose-response curves with GraphPad Prism software.

\section{Luciferase reporter gene activity assay}

As previous reported method with slight modifications, ${ }^{23}$ the effect of isolated compounds on RANKL-induced NF- $\kappa$ B activation was conducted using RAW 264.7 cells stably transfected 
with an NF- $\kappa \mathrm{B}$ driven luciferase reporter gene construct $(3 \mathrm{kB}$ Luc-SV40). Various concentrations of isolated compounds (16b) were treated for $1 \mathrm{~h}$ followed by $100 \mathrm{ng} \mathrm{mL} \mathrm{mL}^{-1}$ RANKL for $6 \mathrm{~h}$ on RAW 264.7 cells stably transfected with an NF- $\kappa$ B-driven luciferase reporter gene. Luciferase activities were measured using a Promega Luciferase Assay System (Promega, Madison, WI, USA), and normalized to that of the vehicle control.

\section{Conclusions}

In summary, seven new (1-4, 5a, 6a, and 7) and two known metabolites $(\mathbf{5 b}, \mathbf{6 b})$ were isolated and identified from the culture of the endophytic fungus $D$. phaseolorum SKS019. Diaporchromanones A-D (1-4) possessing 3-substituted-chroman4-one nucleus are rarely found in natural sources. To the best of our knowledge, the first 3-substituted-chroman-4-one derivative, polivione, was described in $1985 .{ }^{10}$ Diaporchromanones A-D (1-4) descripted in this paper were the second example of the 3-substituted-chroman-4-one analogues. Furthermore, chromanone components are reported for the first time from the Diaporthe sp. Our findings would enrich chemical context of the genus Diaporthe and expand the chemical and biological diversity of chromanones. In bioactivity assays, compounds 36b exhibited moderate inhibitory effects by suppressing RANKLinduced NF- $\kappa$ B activation using RAW 264.7 cell line.

\section{Conflicts of interest}

The authors declare no conflict of interest.

\section{Acknowledgements}

We thank the National Natural Science Foundation of China (21472251, 41276146), the Science \& Technology Plan Project of Guangdong Province of China (2013B021100011), the Key Project of Natural Science Foundation of Guangdong Province (2016A040403091), Special Financial Fund of Innovative Development of Marine Economic Demonstration Project (GD2012D01-001), China Postdoctoral Science Foundation Funded Project (2013M542223), and China's Marine Commonwealth Research Project (201305017) for generous support.

\section{Notes and references}

1 S. Saengchantara and T. Wallace, Nat. Prod. Rep., 1986, 3, 465-475.
2 W. Y. Tsui and G. D. Brown, Phytochemistry, 1996, 43, 871876.

3 D. L. Zhao, C. L. Shao, L. S. Gan, M. Wang and C. Y. Wang, J. Nat. Prod., 2015, 78, 286-293.

4 T. Ishikawa, Y. Oku, T. Tanaka and T. Kumamoto, Tetrahedron Lett., 1999, 40, 3777-3780.

5 F. Cottiglia, B. Dhanapal, O. Sticher and J. Heilmann, J. Nat. Prod., 2004, 67, 537-541.

6 D. G. Wei, G. F. Yang, J. Wan and C. G. Zhan, J. Agric. Food Chem., 2005, 53, 1604-1611.

7 G. Wu, G. Yu, T. Kurtán, A. Mándi, J. Peng, X. Mo, M. Liu, H. Li, X. Sun and J. Li, J. Nat. Prod., 2015, 78, 2691-2698.

8 D. J. Payne, J. A. Hueso-Rodríguez, H. Boyd, N. O. Concha, C. A. Janson, M. Gilpin, J. H. Bateson, C. Cheever, N. L. Niconovich and S. Pearson, Antimicrob. Agents Chemother., 2002, 46, 1880-1886.

9 M. Huang, J. Li, L. Liu, S. Yin, J. Wang and Y. Lin, Mar. Drugs, 2016, 14, 215.

10 A. K. Demetriadou, E. D. Laue, F. J. Leeper and J. Staunton, J. Chem. Soc., Chem. Commun., 1985, 762-764.

11 J. W. Blunt, B. R. Copp, R. A. Keyzers, M. H. G. Munro and M. R. Prinsep, Nat. Prod. Rep., 2014, 31, 160-258.

12 H. Cui, J. Yu, S. Chen, M. Ding, X. Huang, J. Yuan and Z. She, Bioorg. Med. Chem. Lett., 2017, 27, 803-807.

13 Y. Liu, Q. Yang, G. Xia, H. Huang, H. Li, L. Ma, Y. Lu, L. He, X. Xia and Z. She, J. Nat. Prod., 2015, 78, 1816-1822.

14 H. Cui, Y. Liu, Y. Nie, Z. Liu, S. Chen, Z. Zhang, Y. Lu, L. He, X. Huang and Z. She, Mar. Drugs, 2016, 14, 86.

15 Z. Liu, Y. Chen, S. Chen, Y. Liu, Y. Lu, D. Chen, Y. Lin, X. Huang and Z. She, Org. Lett., 2016, 18, 1406-1409.

16 Y. Liu, G. Xia, H. Li, L. Ma, B. Ding, Y. Lu, L. He, X. Xia and Z. She, Planta Med., 2014, 80, 912-917.

17 S. Chen, Y. Liu, Z. Liu, R. Cai, Y. Lu, X. Huang and Z. She, RSC Adv., 2016, 6, 26412-26420.

18 S. A. Ahmed, S. A. Ross, D. Slade, M. M. Radwan, I. A. Khan and M. A. Elsohly, Tetrahedron Lett., 2008, 49, 6050-6053.

19 D. Slade, D. Ferreira and J. P. J. Marais, Phytochemistry, 2005, 66, 2177-2215.

20 J. Frelek and W. J. Szczepek, Tetrahedron: Asymmetry, 1999, 10, 1507-1520.

21 M. Gerards and G. Snatzke, Tetrahedron: Asymmetry, 1990, 1, 221-236.

22 Y. Wang, Z. Zheng, S. Liu, H. Zhang, E. Li, L. Guo and Y. Che, J. Nat. Prod., 2010, 73, 920-924.

23 S. Yang, X. Li, L. Cheng, H. Wu, C. Zhang and K. Li, Biochem. Biophys. Res. Commun., 2015, 466, 615-621. 